\title{
Attitudes of Czech College Students Toward Digital Literacy and Their Technical Aids in Times of COVID-19
}

\author{
https://doi.org/10.3991/ijep.v11i4.20821 \\ Katarína Krpálková Krelová (两), Kateřina Berková, Pavel Krpálek \\ Prague University of Economics and Business, Prague, Czech Republic \\ katarina.krelova@vse.cz \\ Andrea Kubišová \\ College of Polytechnics Jihlava, Jihlava, Czech Republic
}

\begin{abstract}
At present, when the whole world is struggling with the COVID19 pandemic, it is important to address both the issue of flexibility when educating the younger generation and the issue of further professional education, which contributes to the development of competences that are directly relevant to life and everyday activities in the $21^{\text {st }}$ century. The common denominator of these competences is digital competence. It is the aspect of education that is of primary and crucial importance for digital literacy development. This research study aims at establishing the availability of digital media and attitudes towards one's own technical aids and digital literacy among students of two higher education institutions in the Czech Republic. Empirical research involved 1233 college students. The set research hypotheses were tested with a questionnairebased survey using the Likert scale. A cluster analysis was conducted in the SPSS program. In view of the ordinal nature of data, the nonparametric MannWhitney $U$ test conducted at significance levels of 5\% and 1\% in SPSS was applied to test the dependence of competence self-assessment on the specialization of the higher education institutions/ study level/ study form. The research has unequivocally proven that digital literacy is influenced by the study programme specialization, study level and study form.
\end{abstract}

Keywords - Education, Digital literacy, Form of education, Economic and humanities studies

\section{Introduction}

The current turbulent development of society with all the associated risks and problems, but also the opportunities and challenges of the times is taking place under conditions of the accelerating Fourth Industrial Revolution, known as Industry 4.0. The fourth industrial revolution is characterised by digitalisation, sharing and a circular economy. These macrotrends are expanding into all sectors of the economy and are fundamentally changing the demands on education, structure and occupational activities. They are also altering the way we live, work, cooperate and communicate. The 
expansion of digital technologies and the emphasis on sharing and sustainability will also have a significant impact on the spheres of education, labour market and employment [1], [2]. That is to say, there are considerable and ever-accelerating changes in the occupational and qualification structure along with the gradually transforming job descriptions and competence profiles of most professions. Some occupations have disappeared, some, non-existent in the past, have emerged and are subject to constant modification. In this context, it is important to address both the issue of flexibility in educating the younger generation and the issue of further (professional and retraining) education, which contributes to the development of competences directly relevant to life and everyday activities in the 21 st century and simultaneously those required by the labour market [3], [4]. he common denominator among these transversal competences is digital competence. It is the aspect of education that is of primary and crucial importance for digital literacy development [5], [6].

Currently, the whole world is struggling with the COVID-19 pandemic, which has hit all sectors of the economy hard, including educational institutions. Practically, from one day to another, it was necessary to make a transition from the in-person to remote form of learning at all levels of education. Schools had to face problems related to the availability of digital means to teachers and students, as well as their standard of digital literacy, which often proved to be an even more serious problem. So far, the use of digital means and online teaching tools has been regarded by many higher education institutions only as an additional instrument for teaching in the combined form of education. The emergency situation and the governmental crisis measures brought restrictions to in-person lessons and the gradual full transition to remote learning, to which teachers and students were forced to respond and adapt flexibly. In order to make online lessons and learning processes effective it is essential for all those involved to be equipped not only with the necessary IT infrastructure, but also and particularly - with developed digital competences. Therefore, there is dual pressure on the development of digital competences: one being universal, objectively stemming from the current technological development of society and the other specific, connected with extraordinary situations, currently the crisis impacts of the epidemiological situation in society, requiring a switch to online forms of teaching [1], [7].

Practical use of a wide range of digital technology resources from the very stage of preparation for future occupations increases not only the level of digital literacy in a desirable way, but also reflects positively in attitudes of students towards modern educational technologies based on information and communication technologies and strengthens the relationship with digital technologies. The authors claim that social media as a modern tool of cognition and as an integral part of key competences for the 21 st century also contribute significantly to the increase in digital competences [8].

The aim of the research study was to assess the availability of digital media and attitudes toward one's own technical aids and digital literacy among students of two higher education institutions in the Czech Republic in times of COVID-19. A total of 1233 students participated on a voluntarily basis in the research that was carried out in April and May 2020. The need for research was brought about by the existing unfavourable educational situation caused by the global pandemic. The research objective reflects the necessary transition from the in-person form of education to a remote 
form, using digital media and other online means of remote teaching. The situation regarding attitudes toward technical aids and digital literacy was evaluated in students of bachelor and master study programmes of two Czech universities specializing in humanities and economics - Prague University of Economics and Business and Jan Amos Komenský University, Prague. The survey focused on identifying the differences between students according to the study specialization and form and level of study. The research objective produced the following substantive hypotheses:

- H1: Students' individual attitudes toward digital literacy correlate with each other.

- H2: Students' attitudes toward digital literacy vary according to their study specialization.

- H3: Students' attitudes toward digital literacy vary according to the level of their study.

- H4: Students' attitudes toward the level of digital literacy vary according to the form of their study.

In methodological terms, the research was inspired by an empirical study based on the assessment of attitudes toward digital literacy of healthcare staff [9] and the research on digital literacy of the Slovak population [2], [10].

The benefits of the current research are evident in the possible innovation of education strategies that will mitigate the impacts of the COVID-19 pandemic on education in terms of technical aids, digital literacy and related competences of students.

\section{Literature Review}

The current times affected by the COVID-19 crisis have shown that digital competences that enable online access to information and services (education) are crucial for the whole population. EU leaders have realized the need to strengthen basic and advanced digital skills at all levels of education as they are indispensable for an effective transition to a remote form of learning. That corresponds with the opinions of Varela, Rebollar, García, Bravo, and Bilbao [11], who regard competence in computational thinking and creativity to be one of the key competences that students must acquire in modern education. They understand it as a set of skills and attitudes needed to solve problems that can occur in any area of life, with or without a computer. The authors named in this paragraph consider measuring and evaluating which computational thinking skills students have acquired to be essential. They draw attention to skills such as critical algorithmic thinking, problem solving, collaboration and creativity. Digital competences include not only technical abilities, but also relevant knowledge and attitudes [12]. Digital literacy requires the development of cognitive skills, technical abilities and attitudes in the areas [1], [13], [14], [28]: 
- Computer literacy: Command of digital technologies enabling educational activities to be carried out with ease (use of computer, network, internet as a working tool); instrumental knowledge and skills for the effective use of digital tools and means.

- Information literacy: Ability to search for, interpret, evaluate and process information;

- Media literacy: Competence to critically examine, evaluate and create media communications;

- Communication and cooperation: Self-active involvement in collaborating networks promoting cognition; advanced knowledge and skills for communication, learning, problem solving and participation;

- Digital working environment: Incorporating academic and research activities into practice supported by current technologies and social networks;

- Building one's own digital identity: Providing online information about oneself in a controlled manner and controlling one's digital footprint;

- Ability to learn: Mastery of digital technology control enabling learning activities to be carried out, plus attitudes towards the application of relevant knowledge and skills.

The Digital Economy and Society Index [15] has delivered the surprising finding that a large proportion of the EU population still does not have basic digital skills, even though the labour market requires such. Over the past 4 years, the level of digital literacy has slowly increased, with $58 \%$ of the population showing at least basic digital skills and $61 \%$ of the population having at least basic software skills. However, the indicators of skills are strongly influenced by socio-demographic aspects and the standard of the optical internet connection network. The differences between EU member states are significant. It is still possible to find areas in the Czech Republic with no or very limited internet connection, which obviously has a major impact on the development of digital skills.

The authors [4] scientifically confirmed that digital competences are a statistically important factor for the transformation of human capital in the 21 st century. However, the use of the internet itself does not bring any added value as such. In [10] the highest level of digital literacy achieved was identified in working with the internet, with the lowest being attributed to software application control skills. The gender factor, established as statistically significant in hardware indicators to the detriment of women, contributes to the creation of the specific "digital divide" to a certain degree.

On the contrary, some research [29] has not shown significant gender differences in digital literacy rates. In Slovakia, the creation of the digital divide is influenced by anticipated factors, which are mainly age and education [10], [16]. As regards the digital divide caused by access to means (the internet), it is important for state policy to become actively involved in this aspect. In this sense, the government must guarantee free and universal access to technologies to all of its citizens in order to reduce the digital divide between them [17]. The use of digital technologies increases the level of digital literacy and has the effect of positively influencing attitudes towards modern educational technologies. Research has proven the causal impact of the frequency of 
use of digital devices and computers on attitudes towards modern information and communication technologies [18]. In order for students to have a positive relationship with modern digital means, it is essential that these are more massively incorporated in the teaching and learning process. Thanks to technological integration, students have better possibilities of interacting with their peers, teachers and teaching materials. The choice of forms of digital means representation should correspond to the personal characteristics and preferences of student [19], [20]. From the point of view of the teacher and the teaching process, it is information literacy, communication and cooperation as well as the creation of digital content that appear to be of key importance. Research shows that the weak spot lies in the creation of digital content. Students generally feel able to work with information and are moderately capable of communicating and communicating safely, but have difficulty creating content and lack problem solving skills. Therefore, the deficit lies in the area of transversal competences. Creativity in the production of audio-visual materials is essential for coding content and information in an academic, personal and professional context. The formal educational context is normative, with little room for creativity and autonomy. It is appropriate to transform digital competences acquired through informal learning into an academic (formal) environment, and the link between the formal and informal learning contexts can significantly enhance student motivation [21]-[23]. In this context the need for a closer connection between the university and society has been currently emphasized, along with the support of the professional development of higher education teachers, because the level of their digital literacy significantly influences, through their teaching styles, attitudes and development of students' digital literacy. For this reason, it is necessary to promote their co-learning [3], [24].

\section{$3 \quad$ Methodology}

\subsection{Research sample}

The research sample was made up of students of bachelor and master study programmes focused on humanities and economics in two Czech universities. The schools and respondents were chosen by purposive sampling. The main criterion for the selection of the two universities - Prague University of Economics and Business (PUEB) and Jan Amos Komenský University, Prague (JAKUP) - was the employment of the authors in these schools as teachers. This made it possible to set up a research tool in a more friendly way and thereby gain a better insight into the interpretation of the research results toward the definition of the research-related recommendations.

The research was participated in by 1233 students on a voluntary basis with a $30 \%$ response rate from Prague University of Economics and Business, namely from the Faculty of Finance and Accounting, and with a 10\% response rate from Jan Amos Komenský University, Prague. The sample consists of students of humanities and economic disciplines of bachelor and master degree courses of both full-time and combined forms of study. The sample structured according to study level is depicted 
in the following tables, which indicate the relative frequencies of individual categories separately for each of the universities. See Table 1, 2.

Table 1. Structure of the research sample - level of study (\%)

\begin{tabular}{|l|c|c|c|}
\hline \multirow{2}{*}{ Higher education institution } & \multicolumn{2}{c|}{ Level of Study } & \multirow{2}{*}{ Total } \\
\cline { 2 - 3 } & Bachelor & Master & \\
\hline UEP & $476(38.6 \%)$ & $287(23.3 \%)$ & $763(61.9 \%)$ \\
\hline JAKUP & $310(25.1 \%)$ & $160(13.0 \%)$ & $470(38.1 \%)$ \\
\hline Total & $786(63.7 \%)$ & $447(36.3 \%)$ & $1233(100.0 \%)$ \\
\hline
\end{tabular}

Table 2. Structure of the research sample - form of study

\begin{tabular}{|l|c|c|c|}
\hline \multirow{2}{*}{ Higher education institution } & \multicolumn{2}{c|}{ Form of Study } & \multirow{2}{*}{ Total } \\
\cline { 2 - 3 } & Full time & Combi & \\
\hline UEP & $763(61.9 \%)$ & $\mathrm{x}^{*}$ & $763(61.9 \%)$ \\
\hline JAKUP & $95(7.7 \%)$ & $375(30.4 \%)$ & $470(38.1 \%)$ \\
\hline Total & $858(69.6 \%)$ & $375(30.4 \%)$ & 1233 \\
& $(100.0 \%)$ \\
\hline
\end{tabular}

* The Finance and Accounting Faculty of the PUEB does not provide a combined form of study on either of the study levels.

The method of drawing the sample was conditional on the COVID-19 pandemic, when it was necessary to determine the technical skills of students, attitudes toward digital literacy and their own technical aids. For this reason, technical disciplines were not included in the sample, as the universities being examined do not provide technical education.

We consider the sample representative in view of the structure in terms of technical aids for remote education. Students have significant resources necessary for remote learning and online communication with the teacher. See Figure 1.

The majority of students $(91.3 \%)$ use the internet to work with information in the course of their school work. $6.1 \%$ of respondents use library services, $1.8 \%$ of students go on social media, chat, or skype for this purpose, and $0.8 \%$ of the surveyed participants favour professional media (newspapers, journals).

The internet is most commonly used by students at home. This answer was given by $78.7 \%$ of respondents. Other options recorded considerably smaller shares - namely, the internet at hostels $(8.8 \%)$, at work $(4.6 \%)$, mobile data use $(3.8 \%)$, at school $(3.3 \%)$ and at a café or a friend's house $(0.8 \%)$. 


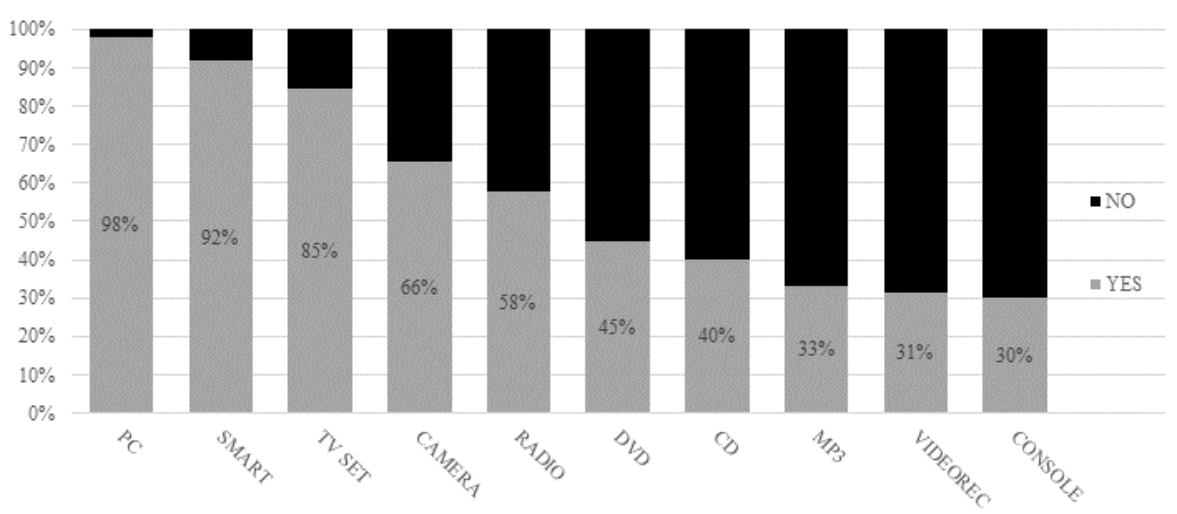

Fig. 1. Students' technical aids

\subsection{Data collection and methodology}

Data collection was based on a questionnaire method within the quantitative research. The collection took place in April and May 2020, which was at that time the period of the greatest pandemic-related crisis in the Czech Republic, when students could not be personally present at school. A non-standardized web-based questionnaire was prepared for the research purposes, containing questions relevant to the research objective. The questionnaire was inspired by the one used to research the digital literacy of the Slovak population drawn up by the authors [10]. The method and practice of wording and evaluating questions are based on international research [9], [25]. The survey method for assessing respondents' attitudes is also frequently used in education, and has therefore been selected in view of the quantitative nature of the research [26].

The survey was conducted anonymously and remotely using school e-mail communication with students. The questionnaire was divided into three sections.

Considered important in describing the structure of the research sample, the first section identified the technical aids of students, and consisted of three questions:

- What kind of media do you have at home?

- Where do you use the internet most often?

- In which media would you search for information for your school work?

Nominal variables were applied for this set of questions. Their classification under the above questions is depicted in Table 3 (see Table 3).

The second section of the questionnaire was aimed at assessing students' attitudes toward competences that represent digital literacy. Digital literacy is defined by 27 competences relevant to civic life and education at school. On this issue the questionnaire structure was inspired by the study [25]. Students rated themselves using the Likert scale ranging from 1 - I am excellent at this competence, to 5 - I have no grasp of this competence whatsoever. 
These competences have been included in the model. See Table 4. Each competence is accompanied with an abbreviation which the authors use in the subsequent parts of the article.

Table 3. Description of the data from the first questionnaire section - technical aids

\begin{tabular}{|l|l|}
\hline \multicolumn{1}{|c|}{ Question } & \multicolumn{1}{c|}{ Variables } \\
\hline What kind of media do you have at home? & $\begin{array}{l}\text { TV, radio, DVD/video, computer/laptop, CD player, MP3 } \\
\text { player, game console, camcorder, camera, smart-phone }\end{array}$ \\
\hline Where do you use the internet most often? & $\begin{array}{l}\text { At home, in the hostel (in the school accommodation facility), } \\
\text { at school, in an internet café, at friends' houses, I usually don't } \\
\text { use the internet, different answer }\end{array}$ \\
\hline $\begin{array}{l}\text { In which media would you search for } \\
\text { information for your school work? }\end{array}$ & $\begin{array}{l}\text { Newspaper/journals, TV/radio, search tools on the internet, } \\
\text { social networks/chat/skype, different answer }\end{array}$ \\
\hline
\end{tabular}

Table 4. The examined competences of digital literacy and their abbreviations

\begin{tabular}{|l|l|}
\hline \multicolumn{1}{|c|}{ Competences } & \multicolumn{1}{|c|}{ Abbreviations } \\
\hline 1) Use of a computer (desktop, laptop) & PC \\
\hline 2) Use of mobile devices (iPad, smartphone, tablet) & MOBILE \\
\hline 3) Installation of pc peripherals & PERIPH \\
\hline 4) Computer connection to the internet & INT \\
\hline 5) Working with an operating system - basic knowledge of the OS & OS_BK \\
\hline $\begin{array}{l}\text { 6) Working with an operating system - hardware and software } \\
\text { administration }\end{array}$ & OS_HWSW \\
\hline 7) Use of a text processor & TEXT \\
\hline 8) Use of spreadsheet software & TAB \\
\hline 9) Use of a presentation program & PRES \\
\hline 10) Use of a database program & D_BASE \\
\hline 11) Use of a graphic editor & GRAPH \\
\hline 12) Use of a multimedia program & MULTI \\
\hline 13) Use of an internet search engine & SE_ENGI \\
\hline 14) Use of a personal information management program & P_INFO \\
\hline 15) Use of anti-virus programs & ANTI_V \\
\hline 16) Software installation & SW_INST \\
\hline 17) Search for information and services on the internet & SE_INFO \\
\hline $\begin{array}{l}\text { 18) Registration for access to information and services on the } \\
\text { internet }\end{array}$ & REGIST \\
\hline 19) Sending and receiving e-mails & E_MAIL \\
\hline 20) Communicating via online chat (video chat) & CHAT \\
\hline 21) Communicating in newsgroups, forums & FORUM \\
\hline 22) Communicating in social networks on the internet & SOC_NET \\
\hline 23) Telephoning over the internet & TELEPH \\
\hline 24) Purchase of goods and services over the internet & E_SHOP \\
\hline 25) Use of internet banking & BANK \\
\hline 26) Communication with authorities and institutions through elec- \\
tronic forms & E_FORM \\
\hline 27) Knowledge of security risks when using the internet & SECUR \\
\hline & \\
\hline
\end{tabular}


The third section of the questionnaire contained questions to establish respondents' factographic data. These were:

- Specialization of the universities (Prague University of Economics and Business economic education / Jan Amos Komenský University, Prague - humanities),

- Level of study (bachelor/subsequent master),

- Form of study (full-time/combined).

Gender and age of respondents were not studied, given that the aim of this study is to assess the differences between the study specialization, level and form of study and, in general, to identify the technical aids of students during the pandemic, regardless of the gender and age of the individual.

Pre-research was carried out prior to the actual research, involving a sample with the characteristics of the respondents from the main research, thus increasing the validity of the content and the reliability of the research tool.

\subsection{Statistical analysis}

The object of the statistical analysis was the following null hypotheses tested at $95 \%$ and $99 \%$ confidence:

- $\mathrm{H}_{0-1}$ : There is no dependence among the individual attitudes of students toward digital literacy.

- $\mathrm{H}_{0-2}$ : Students' attitudes toward digital literacy do not vary according to their specialization.

- $\mathrm{H}_{0-3}$ : Students' attitudes toward digital literacy do not vary according to the level of their study.

- $\mathrm{H}_{0-4}$ : Students' attitudes toward the level of digital literacy do not vary according to the form of their study.

Subjective assessment on the 5-point Likert scale 1-5 provides ordinal data. With the aim of clearly organizing the outcomes, the characteristics of the positions of the median and arithmetic mean that were used to put the questions in ascending order were calculated employing the methods for working with interval data.

Applying inference statistics, the correlation between the individual pairs of competences was analysed and a correlation table was established with the Pearson's rho coefficients, including their significance.

A cluster analysis was conducted in the SPSS program. Based on their relatedness, 27 competences were divided into clusters. In view of the ordinal nature of data, the non-parametric Mann-Whitney $U$ test conducted at significance levels of 5\% and 1\% in SPSS was applied to test the dependence of competence self-assessment on the specialization of the higher education institution/ study level/ study form. 


\section{$4 \quad$ Results and Discussion}

The research has yielded interesting results. Students' attitudes towards their standard of digital literacy differ in terms of the specialization, form and level of the study. Simultaneously, it has been verified on a sample of 1233 persons that the examined digital literacy competences are correlated and connected. A comparison of these results with international and national studies and an explanation of the correlations are given in the next section of this text.

Proceeding from the descriptive statistics, it was ascertained that on average students are most confident in sending and receiving e-mails (the average value of 1.36) and least in working with a graphic editor (average rating of this competence at 3.15). Applying the Pearson's rho coefficient, the correlation of pairs of the examined competences was tested. Most of the dependences were significant. In nine cases, the level of dependence was higher than 70\%, in four cases even higher than $75 \%$. The highest level of dependence was recorded by the following pairs of characters: Use of an internet search engine (SE_ENGI) - Search for information and services on the internet (SE_INFO) (76.5\%), Communicating via online chat and video chat (CHAT) Telephoning over the internet (TELEPH) $(75.8 \%)$, Use of a text processor (TEXT) Use of spreadsheet software (TAB) (75.5\%) and Use of mobile devices (MOBILE) Use of a computer (PC) $(75 \%)$.

The null hypothesis H0-1 is rejected for 347 competence pairs at the significance level of $5 \%$. This means that competences representing students' digital literacy are correlated and interact with each other.

The results point to the fact that the selected competences are related and can be characterized as digital literacy. This finding corresponds to the definition of computational thinking [11] and digital literacy [12]. The authors named in the previous sentence understand computational (digital) thinking also as a set of skills and habits of an individual usable in everyday life. Further they pay attention to promoting cooperation among the actors. The research has shown that students of the higher education institution in Prague believe that they are best at e-mail communication as a collaboration communication tool, because it is probably used by them most frequently. It is evident that they do not feel so strong with other digital tools supporting effective communication in an online virtual environment. However, these results are not fully in line with the Slovak research [10], [2] which also focused on digital literacy assessment. The e-mail communication skills of respondents reached the value of 2.34 (our research used the same scale). This discrepancy can be explained in particular by the fact that the Slovak research was aimed at the entire population without the specific limitation to higher education institutions and was carried out in 2018. The research time period can be a significant factor in the light of rapidly evolving technologies and communication tools. Therefore, the deterioration of the value may have appeared. However, college students possess higher skills or more likely they use these collaboration tools more frequently. The Slovak research did not examine correlations between digital literacy competences. Similarly, the correlations were not examined in other studies [2], [4], [10], [18], but above all, research is aimed at identifying differ- 
ences in digital competences among groups of respondents. Therefore, we applied the inference statistics of intergroup relations at the level of digital competences.

To meet the needs of the inference statistics of intergroup relations, it was necessary to reduce the number of the evaluated competences from the original 27 . See Figure 2. Due to the dependences established between them, only a few representatives with similar parameters were selected. The element that would be separated from the group last if the set number of clusters was enlarged was always chosen. The competences were grouped into the following six clusters: Basic (1, 2, 4, 7, 8, 9, 13, 17, 18, 19, 20, 21, 22, 23, 24, 25, 27); Advanced (10, 11, 12); Personal information management (14); E-forms (26); Operating system administration (3, 6, 15, 16); Operating system control (5).

The last two clusters were joined into one category. By contrast, the first largest cluster was logically divided into four sub-clusters.

Looking more closely at the largest cluster, it appeared that the following parameters naturally belong together:

- MS Office $(7,8,9,27)$

- Communication $(4,18,20,21,22,23)$

- Shop\&Bank $(13,17,19,24,25)$

- PC\&Mobil $(1,2)$

- Advanced $(10,11,12)$

- Personal info (14)

- E-form (26)

- Operating system $(3,5,6,15,16)$

Eight competence families were put together based on similar characteristics, which were identified by the mathematical statistical method, and at the same time they essentially correspond to the perception of the professional users who employ these tools in their everyday work. It was necessary to choose one representative from each family and subsequently it was further subjected to a dependence analysis according to the set hypotheses. Therefore, this cluster was divided again, on an artificial basis, into four subsets of logically related competences. In total, the number of competences assessed in relation to school/level/form of study decreased to a reasonable 8 areas. 


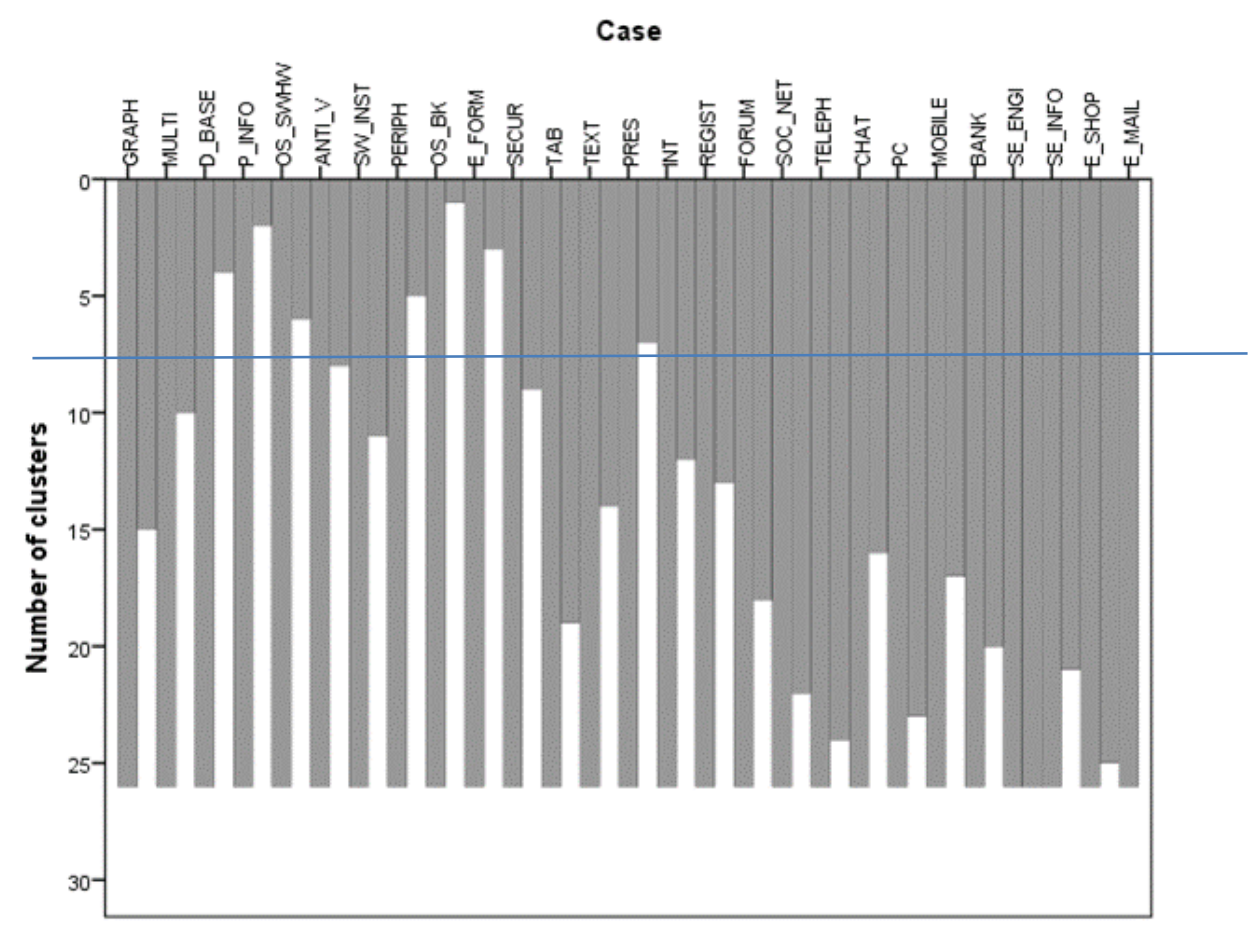

Fig. 2. Cluster analysis of competences

The remaining three null hypotheses were also tested. See Figure 3-5. The first lines indicatively give the average values/medians of self-assessment in the given group, followed by the $\mathrm{U}$ test criterion for the Mann-Whitney test, $\mathrm{W}$ for the Wilcoxon test, $\mathrm{Z}$ criterion and the significance of these tests.

Table 5. Dependence of digital literacy on specialization of the higher education institution

\begin{tabular}{|l|c|c|c|c|c|c|c|c|}
\hline & GRAPH & P_INFO & SW_INST & E_FORM & TAB & TELEPH & SE_ENGI & PC \\
\hline PUEB & 3.22 & 2.76 & 2.44 & 2.39 & 2.04 & 1.62 & 1.58 & 1.68 \\
\hline JAKUP & 3.05 & 2.70 & 2.81 & 2.02 & 2.35 & 1.76 & 1.54 & 1.86 \\
\hline MW U & 164674 & 173612 & 151885 & 144476 & 147548 & 164910 & 173904 & 154384 \\
\hline $\begin{array}{l}\text { Wilcox- } \\
\text { on W }\end{array}$ & 275359 & 284297 & 443351 & 255161 & 439014 & 456376 & 284589 & 445850 \\
\hline Z & -2.484 & -0.966 & -4.642 & -5.962 & -5.485 & -2.751 & -1.051 & -4.509 \\
\hline Sig. & $.0 .13^{*}$ & .334 & $.000^{* *}$ & $.000^{* *}$ & .000 & $.006^{* *}$ & .293 & $.000^{* *}$ \\
\hline
\end{tabular}

*Correlation is significant at the 0.05 level.

** Correlation is significant at the 0.01 level.

The null hypothesis H0-2 is rejected at the indicated levels of significance for Use of a graphic editor (11), Software installation (16), Communication with authorities and institutions through electronic forms (26), Use of spreadsheet software (8), Telephoning over the internet (23), Use of a computer (desktop, laptop) (1). With respect 
to these areas, differences have been identified in terms of the subjective assessment of students' own skills, namely with regard to the specialization of the higher education institution. See Table 5.

Table 6. Dependence of digital literacy on the study programmes

\begin{tabular}{|l|c|c|c|c|c|c|c|c|}
\hline & GRAPH & P_INFO & SW_INST & E_FORM & TAB & TELEPH & SE_ENGI & PC \\
\hline Bach. & 3.18 & 2.71 & 2.64 & 2.31 & 2.20 & 1.66 & 1.56 & 1.76 \\
\hline Mast. & 3.10 & 2.79 & 2.48 & 2.14 & 2.09 & 1.71 & 1.57 & 1.72 \\
\hline MW U & 1668371 & 169501 & 165328 & 158302 & 161439 & 170923 & 172787 & 167612 \\
\hline $\begin{array}{l}\text { Wilcox- } \\
\text { on W }\end{array}$ & 268499 & 478792 & 265456 & 258430 & 261567 & 480214 & 272915 & 267740 \\
\hline Z & -1.252 & -1.057 & -1.769 & -3.004 & -2.483 & -0.917 & -0.567 & -1.473 \\
\hline Sig. & .210 & .290 & .077 & $.003^{* *}$ & $.013^{*}$ & .359 & .571 & .141 \\
\hline
\end{tabular}

*Correlation is significant at the 0.05 level.

** Correlation is significant at the 0.01 level.

The null hypothesis $\mathrm{H} 0-3$ is rejected at the indicated levels of significance for Communication with authorities and institutions through electronic forms (26), Use of spreadsheet software (8). With respect to these areas, differences have been identified in terms of the subjective assessment of students' own skills, namely with regard to the level of study which was researched on the level of bachelor and subsequent master study programmes. See Table 6.

Table 7. Dependence of digital literacy on the form of study

\begin{tabular}{|l|c|c|c|c|c|c|c|c|}
\hline & GRAPH & P_INFO & SW_INST & E_FORM & TAB & TELEPH & SE_ENGI & PC \\
\hline FT & 3.20 & 2.74 & 2.51 & 2.39 & 2.10 & 1.62 & 1.57 & 1.68 \\
\hline Comb. & 3.05 & 2.73 & 2.74 & 1.92 & 2.30 & 1.81 & 1.57 & 1.91 \\
\hline MW U & 149370 & 159590 & 144871 & 122940 & 141652 & 142996 & 159902 & 134114 \\
\hline $\begin{array}{l}\text { Wilcox- } \\
\text { on W }\end{array}$ & 219870 & 230090 & 513382 & 193440 & 510163 & 511507 & 230402 & 502625 \\
\hline Z & -2.063 & -02.30 & -2.861 & -6.855 & -3.505 & -3.607 & -0.200 & -5.112 \\
\hline Sig. & $.039^{*}$ & .818 & $.004^{* *}$ & $.000^{* *}$ & $.000^{* *}$ & $.000^{* *}$ & .841 & $.000^{* *}$ \\
\hline
\end{tabular}

*Correlation is significant at the 0.05 level.

** Correlation is significant at the 0.01 level.

The null hypothesis H0-4 is rejected at the indicated levels of significance for Use of a graphic editor (11), Software installation (16), Communication with authorities and institutions through electronic forms (26), Use of spreadsheet software (8), Telephoning over the internet (23), Use of a computer (desktop, laptop) (1). With respect to these areas, differences have been identified in terms of the subjective assessment of students' own skills, namely with regard to the form of study which was based on the full-time and combined types of study. See Table 7. This means that competences representing students' digital literacy are correlated and interact with each other.

The results above can be considered as consistent with the research [16], which has shown that digital literacy is influenced by education. In our case, it is also influenced by education, but from the point of view of the certain specialization of the study programme, the level and form of study. The authors focused on the standard of quali- 
ty of online teaching using MS Teams and Zoom compared to in-person teaching in the study discipline of mechanical engineering and came to the conclusion that there was no decrease in knowledge-related performance, but students preferred in-person learning in practical forms of teaching, where the emphasis is placed on project and team work, which also represents the added value of social competence development [27]. A similar view is shared by Tiejun, who states that for higher education students there is no significant difference in learning in person or online, while confirming that the online form of teaching is not effective for practically oriented courses [7].

Research did not take into account disciplines other than economic and humanities, nor did it examine gender differences. Obviously, this absence limits this empirical study. However, it should be noted that this is pilot research, which will continue to be extended by other parameters that may be crucial in terms of digital literacy and attitudes not only of students but also of other population groups.

The development of digital and information literacy of students should take place continuously during preparation for a future occupation and subsequently in the course of lifelong learning [5]. It is important for education participants to be able to make effective use of modern technologies that will enable them to further develop professional competences [6].

\section{Conclusion}

Based on the above results of the content analysis and original empirical research, it is possible to unequivocally confirm that the study programme specialization, level and form of study significantly influence digital literacy. Competences expressing digital literacy were measured by the subjective perception of respondents, i.e. through their attitudes towards their standard, namely from the point of view of students of humanities and economic disciplines. It was established that students were most confident in using the communication tools that they use every day (e-mail), and relatively less in using applications such as graphic processors, spreadsheets, database systems, etc. In present times it is obvious that digital literacy demands will increase hand in hand with e-learning, online lessons, learning management systems and related applications and the communication environment becoming a common part of learning techniques. Therefore, we see considerable potential in follow-up research and in-depth analyses of the conditions for the development of digital literacy, and we intend to further develop this pilot research.

\section{Acknowledgement}

This research was supported by Project No. IGS Prague University of Economics and Business F1/7/2018, Project Prague University of Economics and Business No. IP 100040. The authors would like to thank the students of Prague University of Economics and Business and Jan Amos Komenský University, Prague. 


\section{$7 \quad$ References}

[1] Krpálek, P., Krpálková Krelová, K. (2019). Innovation in Training of Economics Teachers in Terms of Digital and Media Literacy, In the Utilization of Teachers' Digital Literacy in Teaching. TTnet Specialist Conference ČR, Beroun, Praha: Národní ústav pro vzdělávání, pp. 38-42, 2019. Available: http://www.nuv.cz/uploads/TTnet_2018/TTnet_2019B.pdf. [Accessed Sep 15, 2020]. https://doi.org/10.22616/reep.2019.009

[2] Krpálková Krelová, K. (2020). Digital literacy of students of the University of Economics in Prague, $12^{\text {th }}$ International Scientific Conference Competition, College of Polytechnics Jihlava, November 19 2020, Jihlava, Czech Republic. pp. 252-261, 2020. https://doi.org/10.24818/ea/2018/s12/1040

[3] Tugun, V., Bayanova, A. R., Erdyneeva, K. G., Mashkin, N. A., Sakhipova, Z. M., Zasova. L. V. (2020). The Opinions of Technology Supported Education of University Students. International Journal of Emerging Technologies in Learning (iJET), 15(23), pp. 4-14, 2020. https://doi.org/10.3991/ijet.v15i23.18779

[4] Rozite, K., Balina, S. \& Freimane, R. (2019). Digital competence rating and economic development in the EU, New Challenges of Economics \& Business Development, pp. 701708, 2019. Available: http://web.a.ebscohost.com.zdroje.vse.cz:2048/ehost/pdfviewer/pdf viewer?vid=28\&sid=52decc72-b6e3-434e-85c2-7f11d2d011a9\%40sessionmgr4006 . [Accessed Sep 17, 2020].

[5]Simonova, I., Bilek, M. (2012). Ten years of eLearning within the Engineering Education in the Czech Republic. International Journal of Engineering Pedagogy (iJEP), 2(3), pp. 29 39. https://doi.org/10.3991/ijep.v2i3.2095

[6] Serafín, Č. (2019). Information Science in Technical Education Process in Czech Republic, International Journal of Engineering Pedagogy (iJEP), 9 (5), pp. 89-102, 2019. https://doi.org/10.3991/ijep.v9i5.11142

[7] Tiejun Z. (2020). Empirical Research on the Application of Online Teaching in Chinese Colleges and Universities Under the Situation of Novel Coronavirus Pneumonia Prevention and Control. International Journal of Emerging Technologies in Learning (iJET), 15(11), pp. 119-136. https://doi.org/10.3991/ijet.v15i11.13935

[8] Tsvetkova, M., Ushatikova, I., Antonova, N., Salimova, S., Degtyarevskaya, T. (2021). The Use of Social Media for the Development of Digital Literacy of Students: From Adequate Use to Cognition Tools. International Journal of Emerging Technologies in Learning (iJET), 16(2), pp. 65-78, 2021. https://doi.org/10.3991/ijet.v16i02.18751

[9] Kuek, A., Hakkennes, S. (2020). Healthcare staff digital literacy levels and their attitudes towards information systems, Health Informatics Journal, 26(1), pp. 592-612, 2020. https://doi.org/10.1177/1460458219839613

[10] Kokles, M., Romanová, A., Zelina, M., Hamranová, A. (2017). Research o Digital Literacy of Population in the Slovak Republic. Journal of Technology and Information Education, 9(1), pp. 175-188, 2017. Available: https://www.researchgate.net/publication/31448989 8_VYSKUM_DIGITALNEJ_GRAMOTNOSTI_POPULACIE_V_SLOVENSKEJ_REPU BLIKE . [Accessed Apr 29, 2020]. https://doi.org/10.5507/jtie.2017.002

[11] Varela, C., Rebollar, C., García, O., Bravo, E., Bilbao, J. (2013). Skills in computational thinking of engineering students of the first school year, Heliyon, 5(11), 2019, https://doi.org/10.1016/j.heliyon.2019.e02820.

[12] Ferrari, A. (2013). DIGCOMP: A Framework for Developing and Understanding Digital Competence in Europe, 2013. Available: http://bit.ly/1pm1qya . [Accessed Sep 15, 2020]. 
[13] Ala-Mutka, K. (2011). Mapping Digital Competence: Towards a Conceptual Understanding, European Union, Seville, p. 46, 2011. Available: http://ftp.jrc.es/EURdoc/JRC670 75_TN.pdf. [Accessed Apr 30, 2020].

[14] Krpálková Krelová, K., Vrbová, D. (2020). Microlearning as a Modern Form of Education. Views of a Secondary School Teacher of Professional Subjects, Prague : Extrasytem, 2020, pp. 110-119. Available: http://www.extrasystem.com/9788087570487.pdf [Accessed Dec 12, 2020].

[15] Digital Economy and Society Index (DESI). (2020). Thematic chapters. Available: https://ec.europa.eu/digital-single-market/en/desi [Accessed Sep 16, 2020].

[16] Wild, S., Schulze Heuling, L. (2020). How do the digital competences of students in vocational schools differ from those of students in cooperative higher education institutions in Germany?, Empirical Research in Vocational Education and Training, 12(1), pages not numbered, 2020. https://doi.org/10.1186/s40461-020-00091-y.

[17] Llorent-Vaquero, M., Tallón-Rosales, S., Monastero, B.H. (2020). Use of information and communication technologies (ICTs) in communication and collaboration: A comparative study between university students from Spain and Italy, Sustainability (Switzerland), 12(10), 3969, pages not numbered 2020. https://doi.org/10.3390/su12103969.

[18] Romero Martínez, S.J., Ordóñez Camacho, X.G., Guillén-Gamez, F.D., Agapito, J.B. (2020). Attitudes toward technology among distance education students: Validation of an explanatory model, Online Learning Journal, 24(2), pp. 59-75, 2020. https://doi.org/10.24059/olj.v24i2.2028

[19] Asafova E.V., Zeleeva, V.P. (2020). Features of Using Digital and Online Resources by Students of Master's Degree in Pedagogy, Talent Development \& Excellence, 12(3S), pp. 179-187, 2020. Available: http://web.a.ebscohost.com.zdroje.vse.cz:2048/ehost/pdfviewer /pdfviewer?vid=27\&sid=52decc72-b6e3-434e-85c2-7f11d2d011a9\%40sessionmgr4006 [Accessed Sep 17, 2020].

[20] Husin, N.F., Judi, H.M., Hanawi, S.A., Amin, H.M. (2020). Technology integration to promote desire to learn programming in higher education, International Journal on Advanced Science, Engineering and Information Technology, no. 1, pp. 253-259, 2020. https://doi.org/10.18517/ijaseit.10.1.10264

[21] López-Meneses, E., Sirignano, F.M., Vázquez-Cano, E., Ramírez-Hurtado, J.M. (2020). University students' digital competence in three areas of the DigCom 2.1 model: A comparative study at three European universities, Australasian Journal of Educational Technology, 36(3), pp. 69-88, 2020. https://doi.org/10.14742/ajet.5583

[22] Pandian, A., Baboo, S.B., YI, L.J. (2020). Digital storytelling: Engaging young people to communicate for digital media literacy, Jurnal Komunikasi: Malaysian Journal of Communication, 36(1), pp. 187-204, 2020. https://doi.org/10.17576/jkmjc-2020-3601-11

[23] Lopez-Gil, K.S., Garcia, M.L.S. (2020). Development of digital skills of university students in informal learning contexts, Educatio Siglo XXI, 38(1), pp. 53-78, 2020. https://doi.org/10.6018/educatio.413141

[24] Domingo-Coscollola, M., Bosco, A., Segovia, S.C., Valero, J.-A.S. (2020). Fostering teacher's digital competence at university: The perception of students and teachers, Revista de Investigacion Educativa, 38(1), pp. 167-182, 2020. https://doi.org/10.6018/rie.340551

[25] Popa, D., Topala, I.R. (2018). Students' Digital Competencies, Related Attitudes and Self Directed Learning, $14^{\text {th }}$ International Scientific Conference on eLearning and Software for Education - eLearning Challenges and New Horizons, "Carol I" National Defence University Publishing House, April 19-20 2018, Bucharest, Romania. pp. 90-95, 2018. 
[26] Ozturk, G., Ohi, S. (2018). Understanding young children's attitudes towards reading in relation to their digital literacy activities at home, Journal of Early Childhood Research, 16 (4), pp. 393-406, 2018. https://doi.org/10.1177/1476718x18792684

[27] Jacques S., Ouahabi A., Lequeu T. (2020). Remote Knowledge Acquisition and Assessment During the COVID-19 Pandemic. International Journal of Engineering Pedagogy (iJEP), 10(6), pp. 120-138. https://doi.org/10.3991/ijep.v10i6.16205

[28] Janssen, J., Stoyanov, S. (2012). Online Consultation on Experts' Views on Digital Competence. European Commission, 2012. Available: http://ftp.jrc.es/EURdoc/JRC73694.pdf . [Accessed Sep 15, 2020].

[29] Krylova, N.P., Levashov, E.N. (2020). Gender-specific indicators of university students' digital literacy, Science for Education Today, 10(1), pp. 128-148, 2020. https://doi.org/10. 15293/2658-6762.2001.08.

\section{Authors}

Katarína Krpálková Krelová is an assistant professor at the Department of Economic Teaching Methodology at Prague University of Economics and Business and Jan Amos Komenský University, Prague. She focuses on the preparation of future teachers of economics subjects relating to didactics in teaching economics as well as presentation and communication technologies in education and quality management systems in education. She has been actively involved in 18 research projects. She is the author of 2 scientific monographs and has participated in 8 other monographs with her own separate chapter. She has had more than 50 scientific articles published in scientific journals, counting scientific articles indexed in the Scopus database, and more than 90 papers for international conferences, including international conferences indexed in the Web of Science database. She is a member of the International Society for Engineering Pedagogy, Austria, (IGIP) and IACEE - the International Association for Continuing Engineering Education, Atlanta, USA as well as the Council of Higher Education Institutions of the CR.

Contact: Department of Economic Teaching Methodology, Faculty of Finance and Accounting, Prague University of Economics and Business, W. Ch. Square 4, Prague, 130 67, Czech Republic.

Kateřina Berková is an assistant professor at the Department of Economic Teaching Methodology at Prague University of Economics and Business and at the College of Polytechnics, Jihlava. She focuses on the preparation of future teachers of economics subjects, specifically the methodology of accounting at a national and international level, implementation and development of practical subjects based on project teaching, modern teaching methods and development of cognitive process dimensions. She has participated in 17 research projects and is the author of 2 scientific monographs, more than 28 scientific articles in scientific journals including scientific articles indexed in the Scopus database and more than 47 papers for international conferences including the international conferences indexed in the Web of Science database.

Contact: Department of Economic Teaching Methodology, Faculty of Finance and Accounting, Prague University of Economics and Business, W. Ch. Square 4, Prague, 130 67, Czech Republic. 
Pavel Krpálek is an assistant professor at the Department of Economic Teaching Methodology at Prague University of Economics and Business and at the College of International and Public Relations, Prague, where he also holds the position of ViceRector for Science, Research, Creative, Publication and Grant Activities. He is a member of the Academic Council and Vice-President of the Council for Internal Evaluation at the College of International and Public Relations, Prague, a member of the Scientific Council of the Institute for Education and Consultancy of the Czech University of Life Sciences, Prague, a member of the Subject Board of the Doctoral Study Programme - Theory of Teaching Economics Subjects at the University of Economics, Prague, a member of the editorial board of the peer-reviewed electronic journal Media4u for the promotion of education, a member of the scientific editorial board of Extrasystem Praha, o. s. - electronic publishing house and a member of the editorial board of the Journal of Diplomatic and Social Studies. He is the author or coauthor of significant parts of 4 scientific monographs and dozens of articles in scientific journals and proceedings indexed in world scientific databases. He has participated in a number of scientific projects of fundamental and applied research and is also an evaluator of the National Accreditation Office for Higher Education relating to Teaching Economics Subjects.

Contact: Department of Economic Teaching Methodology, Faculty of Finance and Accounting, Prague University of Economics and Business, W. Ch. Square 4, Prague, 130 67, Czech Republic.

Andrea Kubišová is an assistant professor at the Department of Mathematics of the College of Polytechnics Jihlava. She is involved in the teaching of mathematical subjects for finance students mainly with a focus on optimization methods (operational research, mathematical analysis of multivariable functions) and statistical methods. In her publications, she deals with the fuzzy approach in linear optimization and provides statistical data processing support for other research fields. She has participated in 2 research projects and is the author of 2 scientific articles in scientific journals including scientific articles indexed in the Scopus database and 8 papers for international conferences including the international conferences indexed in the Web of Science database.

Contact: Department of Mathematics, College of Polytechnics Jihlava, Tolstého 16, Jihlava, 586 01, Czech Republic.

Article submitted 2020-12-30. Resubmitted 2021-03-01. Final acceptance 2021-03-01. Final version published as submitted by the authors. 